\title{
Simultaneous Determination of Docetaxel and Celecoxib in Porous Microparticles and Rat Plasma by Liquid-Liquid Extraction and HPLC with UV Detection: in vitro and in vivo Validation and Application
}

\author{
Elham Ziaei, Jaber Emami, Moloud Kazemi, and Mahboubeh Rezazadeh
}

Department of Pharmaceutics, School of Pharmacy and Pharmaceutical Sciences, Isfahan University of Medical Sciences, Isfahan, I.R. Iran.

Received, January 29, 2020; Revised, July 6, 2020; Accepted, August 3, 2020; Published, August 4, 2020.

\begin{abstract}
Purpose: A simple, rapid, sensitive, and reliable HPLC method with UV detection was developed and validated for simultaneous quantitation of docetaxel and celecoxib and paclitaxel for dissolution characterization and pharmacokinetic studies. Methods: The HPLC assay was performed isocratically on a reversed-phase C18 $\mu$ Bondapack column using a mobile phase of acetonitrile:water $(45: 55, \mathrm{v} / \mathrm{v})$ at a flow rate of $1.2 \mathrm{~mL} / \mathrm{min}$, and the analytes were detected at $230 \mathrm{~nm}$. Paclitaxel was used as an internal standard for analysis of plasma samples following simple liquid-liquid extraction with n-hexane:isoamyl alcohol (97:3). The method was validated for specificity, linearity, sensitivity, precision, accuracy, robustness, and in vitro-in vivo application. Results: The retention times for docetaxel, paclitaxel, and celecoxib were 10.94, 12.4, and $16.81 \mathrm{~min}$, respectively. The standard curves covering $0.1-1 \mu \mathrm{g} / \mathrm{mL}$ and $0.05-4 \mu \mathrm{g} / \mathrm{mL}$ were linear using dissolution medium and rat plasma, respectively. The limit of quantitation of the method was $50 \mathrm{ng} / \mathrm{mL}$ using $100 \mu \mathrm{L}$ of rat plasma sample and injection of $50 \mu \mathrm{L}$ of the residue. Within- and between-day precision and accuracy did not exceed $16.86 \%$ and $12.10 \%$, respectively. This validated method was successfully used to quantify docetaxel and celecoxib simultaneously in the release study of docetaxelcelecoxib -loaded porous microparticles and pharmacokinetics studies. The methods were found to be simple, specific, precise, accurate, and reproducible. In this study, paclitaxel was used as the internal standard while dexamethasone, flutamide, and budesonide proved suitable alternative as an internal standard. Conclusion: Since docetaxel and celecoxib could be co-administered for the treatment of a wide range of cancers such as non-small cell lung carcinoma, the developed method is particularly advantageous for routine therapeutic drug monitoring and pharmacokinetic studies of these drugs.
\end{abstract}

Abbreviations: CXB, celecoxib; DTX, docetaxel; HPLC, high-performance liquid chromatography; LLE, liquidliquid extraction; LOD, limit of detection; LOQ, limit of quantification; NSCLC, non-small-cell lung carcinoma; PP, protein precipitation; PTX, paclitaxel, SPE, solid phase extraction

\section{INTRODUCTION}

Lung cancer is one of the very common serious cancers accounting for the most cancer-related deaths in both men and women. In recent years many progresses have been made in the treatment of lung cancer, but the efficacy in NSCLC patients have been relatively low (1). Novel combination of chemotherapeutic agents with different mechanisms of action is considered as a new strategy to enhance anticancer efficacy of the drug, minimize emergence of resistance, and reduce adverse side effects. In this direction, combination of selective cyclooxygenase (COX)-2 inhibitors celecoxib with cytotoxic drugs docetaxel has shown synergistic antitumor effect in lung tumor models (2).
Docetaxel is a semi synthetic antineoplastic agent, which is isolated from the needles of the European yew tree Taxus baccata L. docetaxel has shown considerable antitumor effects on broad spectrum of cancers especially NSCLC as the first-line chemotherapeutic agent (1-4). Docetaxel inhibits microtubule depolymerization in the $\mathrm{G} 2 / \mathrm{M}$ cell-cycle phases inducing apoptosis in cancer cells (3-7).

The cyclooxygenase-2 (COX-2) is a key enzyme in arachidonic acid metabolism and prostaglandin production. It is stimulated by growth factors, cytokines, and promoters of cancer cells, leading to the production of PG at the site of inflammation, and is

Corresponding Author: J. Emami, Department of Pharmaceutics, School of Pharmacy and Pharmaceutical Sciences, Isfahan University of Medical Sciences, Isfahan, I.R. Iran. Email: emami@pharm.mui.ac.ir 
involved in cell proliferation (8-11). Expression of COX-2 enzymes, COX-2 mRNA, and protein in various cancers in humans, including lung and especially type NSCLC have been greatly enhanced and are thought to be potentially involved in the pathogenesis of lung cancer (12-18). Recent evidence also indicates that biosynthesis of prostaglandin is increased in cancer cells (19). Celecoxib decreases the intratumor prostaglandin E2 (PGE2) levels via enzymatic inhibition of $\mathrm{COX}-2$ activity without affecting the COX-2 expression (20). Celecoxib, a highly selective COX-2 inhibitor, has shown antitumor effects in human tumor xenograft models of Lewis lung carcinoma (21). Celecoxib also induces apoptosis of cancer cells through inhibition of other mediators involved in the pathogenesis of the disease (22). Due to non-overlapping mechanisms, docetaxel combination with celecoxib for the treatment of NSCLC has shown considerable synergistic effects (2, 23-25). Similar to docetaxel, celecoxib is a lipophilic compound (27) and systemic administration of celecoxib stimulates heart attacks (28).

Lung carcinoma chemotherapy through pulmonary route is considered very efficient as this organ has a large absorptive surface of the alveolar region, delivers drugs directly to the tumor tissues, less systemic availability resulting to lower adverse side effects on normal cells, low metabolic activity in comparison with other routes of administration and avoidance of gastrointestinal and first-pass metabolic degradation (26-28). Therefore, novel and safe drug deliveries are needed in order to supply drug directly to the tumor cells in the lung thereby healthy organs would not be affected by the toxicities of the chemotherapeutic agents.

Porous microspheres with an aerodynamic mean size of 5-30 $\mu \mathrm{m}$ can escape from phagocytic clearance and can be deposited in the deep lung with an enhanced residence time have been proved desirable for pulmonary drug delivery $(29,30)$. Therefore, we have recently designed and developed biodegradable porous PLGA microspheres loaded with docetaxel and celecoxib in order to improve therapeutic efficacy and reduce drug systemic toxicity (unpublished study). Therefore, development and validation of a rapid, simple, and yet sensitive high-performance liquid chromatography (HPLC) method for the quantitation of docetaxel and celecoxib for in vitro and in vivo characterization of developed docetaxel-celecoxib loaded porous microspheres was of primary interest for us.
Reversed-phase HPLC and UV spectrophotometric methods for measurement of celecoxib $(31,32)$ and docetaxel $(33)$ in pure form and in liposomal or solid dosage forms have been reported. However, HPLC methods for concurrent measurements of docetaxel and celecoxib in delivery systems or in biological specimen have not yet been reported.

Sensitive methods for quantification of docetaxel in plasma using liquid chromatography-tandem mass spectrometry following liquid-liquid extraction (LLE), protein precipitation (PP) and/or solid phase extraction (SPE) (34-36), PP with UV detection (37), SPE or LLE with UV detection (38-43) have so far been reported. Measurement of celecoxib in biological fluids following LLE (44-48), PP $(49,50)$, LLE (51, 52) or SPE (53) after PP, and SPE (54-58) have been described.

Generally, PP deteriorates the chromatographic column and reduces the sensitivity of the assay due to sample dilution. SPE procedures is a high cost and time-consuming clean up procedure requiring a large volume of samples unsuitable for the processing of multiple samples in pharmacokinetic studies, and HPLC method based on MS or MS-MS are not affordable or readily available in most laboratories. Our described method does not utilize LC-MS, SPE, $\mathrm{PP}$, or large volume of plasma and yet sensitive. The method is rapid, simple and appropriate for in vitro evaluation and pharmacokinetic studies in small animals and rodents following concurrent administration of docetaxel and celecoxib as with the PLGA porous microparticles developed in our laboratory. Paclitaxel was used as the internal standard (IS) in animal pharmacokinetic studies. This method was validated for its selectivity, accuracy, precision, limit of detection (LOD) and limit of quantification (LOQ) as per ICH guidelines. The validated method was applied in in vitro studies of docetaxel- and celecoxib-loaded porous microparticles and following administration of formulations containing both drugs.

\section{MATERIAL AND METHOD}

\section{Chemicals and reagents}

Docetaxel, celecoxib, paclitaxel, diazepam, flutamide, budesonide, dexamethasone, and poloxamer (pluronic F-127) from Sigma Chemical Co. (St. Louis, MO); diethyl ether, acetonitrile, and methanol from Caledon (Ontario, Canada); n-hexane, isoamyl alcohol, and chloroform from Merck (Germany). All reagents and solutions were either HPLC or analytical grades. 
docetaxel-and celecoxib-containing PLGA porous microparticles were developed and prepared in our laboratory.

\section{Determination of UV wavelength}

The suitable wavelength for simultaneous determination of docetaxel and celecoxib for in vitro study and docetaxel and celecoxib and internal standard (paclitaxel) for in vivo study was achieved by wavelength scanning over the range of $200-400 \mathrm{~nm}$ with a Shimadzu UV-160 (Shimadzu, Japan) double beam spectrophotometer.

\section{Chromatography system and conditions}

The apparatus used was a Waters HPLC system model 746 (USA), consisting of a model 515 intelligent solvent delivery pump, a $100-\mu \mathrm{L}$ injection loop, a computerized system controller, and a Waters 2487 UV detector. Chromatographic separation was performed on a $\mu$-Bondapak C18 $(250 \mathrm{~mm} \times 4.6 \mathrm{~mm}$, Waters, Ireland) column. The mobile phase consisted of water/acetonitrile $(55 / 45 \mathrm{v} / \mathrm{v})$ for in vitro and in vivo studies and eluted at a flow rate of $1.2 \mathrm{~mL} / \mathrm{min}$. The column effluent was detected at $230 \mathrm{~nm}$.

\section{Internal standard and extracting solvent}

To achieve a suitable internal standard for plasma analysis, five drug substances including flutamide, diazepam, paclitaxel, budesonide, and dexamethasone were examined. To test their interference with docetaxel and celecoxib retention times, each compound was injected into the HPLC system individually and in combination with docetaxel and celecoxib. Chromatograms of blank plasma extracted with extracting solvents were also recorded to assess the interference of the analytes with plasma endogenous substances.

\section{Standard solutions of celecoxib, docetaxel and internal standard paclitaxel}

One mg of celecoxib or docetaxel was separately weighed out and their mixture was dissolved in $1 \mathrm{~mL}$ methanol. Solution was further diluted with methanol to obtain 10 and $100 \mu \mathrm{g} / \mathrm{mL}$ standard stock solutions for in vitro and in vivo studies, respectively. Calibration curve standard solutions of $0.1,0.2,0.4$, $0.6,0.8$, and $1 \mu \mathrm{g} / \mathrm{mL}$ were prepared for simultaneous measurement of celecoxib and docetaxel in dissolution medium by further dilution of in vitro standard stock solution in poloxamer $1.5 \%$. For in vivo studies, working standard solutions at concentrations of $0.5,1$, $2.5,5,10,15,20,30$, and $40 \mu \mathrm{g} / \mathrm{mL}$ containing both celecoxib and docetaxel were achieved by further dilution of in vivo standard stock solutions in methanol. paclitaxel (IS) stock solution at concentration of $15 \mu \mathrm{g} / \mathrm{mL}$ was prepared in methanol.

\section{Calibration procedure}

For the preparation of calibration curves in dissolution medium, $30 \mu \mathrm{L}$ of each in vitro working standard solutions were injected into the injection port and drug concentrations versus peak areas for each drug were plotted. To obtain the calibration curve in plasma, 10 $\mu \mathrm{L}$ of in vivo working standard solutions ranging from $0.5-40 \mu \mathrm{g} / \mathrm{mL}$ with paclitaxel (IS) at $15 \mu \mathrm{g} / \mathrm{mL}$ was added into $100 \mu \mathrm{L}$ blank plasma. Drugs standard concentrations ranging from $0.05-4 \mu \mathrm{g} / \mathrm{mL}$ and IS at a fixed concentration of $1.5 \mu \mathrm{g} / \mathrm{mL}$ in plasma was achieved. Five $\mathrm{mL} n$-hexane and isoamyl alcohol (97:3) were added to each tube, vortexed for 2 minutes, and centrifuged at $5,000 \mathrm{rpm}$ for $5 \mathrm{~min}$. The upper layer was then transferred to a clean test tube and evaporated to dryness under nitrogen gas. The residue was reconstituted in $100 \mu \mathrm{L}$ of the mobile phase, mixed well and $50 \mu \mathrm{L}$ of the final clear solution was injected into the HPLC system. By plotting peak area ratios of celecoxib or docetaxel to paclitaxel versus drug concentrations, the calibration curve for each drug was constructed.

\section{Method validation}

\section{Selectivity and specificity}

In order to test the interfering effect of components of porous microparticle matrix with docetaxel, celecoxib, and Paclitaxel peaks, blank microparticles devoid of drugs were prepared in poloxamer $1.5 \% \mathrm{w} / \mathrm{v}$ (used as the external phase in preparation of microspheres), centrifuged, and the upper liquid was removed and injected into the HPLC system. For in vivo tests, blank rat plasma samples without any analyte were pretreated with LLE as described before. The selectivity of the analytical method was confirmed by analysis of a concentration equal to LOQ of the assay method for docetaxel and celecoxib in dissolution medium and plasma. The ability of the method to separate all substances from docetaxel and celecoxib was assessed by a resolution between the peaks corresponding to various compounds. The peak factors were calculated using equations below:

$$
\text { Tailing } f \text { actor }=\frac{W_{5 \%}}{2 \mathrm{~F}}
$$

where, $\mathrm{W}_{5 \%}$ is the peak width at $5 \%$ of the peak height and $\mathrm{F}$ is the front peak half-width. 


$$
\text { Resolution } f \text { actor }=\frac{\mathrm{RT}_{2}-\mathrm{RT}_{1}}{0.5 \times\left(W_{1}+\mathrm{W}_{2}\right)}
$$

where, RT is peak retention time and $\mathrm{W}$ is peak width.

\section{Linearity}

Distribution of the residuals i.e. the percent differences of the back-calculated concentrations (measured) from the nominal (real) concentrations were determined to validate the correlation. For in vitro determinations, the calibration model will be accepted if the residuals are less than $2 \%$ and for in vivo measurements within $20 \%$ for the lower limit of quantifications and within $15 \%$ for all other calibration levels and at least $2 / 3$ of the standards meet this criterion. The calibration curves were also evaluated by the correlation coefficient, slope, and intercept.

\section{Precision, accuracy, and recovery}

The intra- and inter-day variations of the assay in dissolution medium and plasma were determined by replicate analysis of samples at concentrations within the range of calibration curves in a single analytical run on the same day and at three successive days, respectively, using the same stock solutions. The percent coefficient of variance $(\% \mathrm{CV})$ or relative standard deviation (RSD) and accuracy were determined using the following equations.

\section{$\%$ Precision $=($ standard deviation $/$ average concentration $) \times 100$ \\ $\%$ Accuracy $=($ measured concentration $/$ nominal concentration $) \times 100$}

The recoveries of docetaxel and celecoxib at three concentrations of $0.05,1.5$, and $3 \mu \mathrm{g} / \mathrm{mL}$ were evaluated by comparison of the peak areas obtained after extraction of a known amount of docetaxel and celecoxib from plasma with those obtained from the same amounts of drugs in methanol.

\section{Limit of detection (LOD) and limit of quantitation (LOQ) determination}

Limit of detection was determined using the signal-tonoise ratio by comparing the results of the test samples with known concentrations of the analyte to blank samples. The analyte concentration that produced a signal-to-noise ratio of 3:1 was accepted as the LOD. The LOQ was identified as the lowest plasma concentration of the standard curve that could be quantified with acceptable accuracy, precision, and variability.

\section{Robustness}

The robustness of the HPLC method for in vivo measurements was determined by analysis of samples under a variety of conditions such as small changes in the fraction of acetonitrile of the mobile phase, in the $\mathrm{pH}$, and in the mobile phase flow rate. Standard strength of $15 \mu \mathrm{g} / \mathrm{mL}$ was used to prepare the samples. The final nominal concentration of docetaxel and celecoxib and paclitaxel (IS) was $1.5 \mu \mathrm{g} / \mathrm{mL}$. Samples were prepared by the method described before. Percent changes in retention time, tailing factor, resolution factor, peak area ratio, and accuracy were calculated and compared with those obtained for the set-up method.

\section{Application of the method}

\section{in vitro assessment of prepared formulation}

The proposed validated method was utilized for determination of docetaxel and celecoxib in dissolution medium of PLGA porous microparticles containing both drugs. Polymeric PLGA microparticles were prepared by simple $\mathrm{W} / \mathrm{O} / \mathrm{W}$ emulsion. One $\mathrm{mL}$ of docetaxel and celecoxib containing microparticle suspension were added into $24 \mathrm{~mL}$ of dissolution medium directly. The dissolution studies were performed at $37{ }^{\circ} \mathrm{C}$ and $300 \mathrm{rpm}$. In the scheduled time $100 \mu \mathrm{L}$ of the medium were centrifuged at $12,000 \mathrm{rpm}$ for 10 minutes. Residual discarded and $30 \mu \mathrm{L}$ of the clear solution was injected into the HPLC system. docetaxel and celecoxib concentrations in the samples were then calculated using peak area responses and the previously plotted standard curve. This experiment was performed on three independent microparticle formulations.

\section{Pharmacokinetic studies}

Male Wistar rats $(n=3)$, weighing 200-230 g, were obtained from Laboratory Animal Resource Center of School of Pharmacy and Pharmaceutical Science of Isfahan University of Medical Science (Isfahan, Iran). Animals were maintained under normal conditions and allowed free access to water and food. Animal experiments were approved by Iran National Committee for Ethics in Biomedical Research (ethical approval ID: IR.MUI.RESEARCH.REC.1397.387) which was performed in accordance with the Guidelines for the Care and Use of Laboratory Animals. Possible efforts were made to decrease animal numbers and distress. Two mg celecoxib and 2 
mg docetaxel were accurately weighed out and dissolved in a mixture of $130 \mu \mathrm{L}$ ethanol and $200 \mu \mathrm{L}$ Tween 80 and then $670 \mu \mathrm{L}$ normal saline was added and mixed vigorously. The injection volume of the clear solution was adjusted to deliver $5 \mathrm{mg} / \mathrm{kg}$ of either docetaxel or celecoxib through the animals' tail vein. Before and $0.25,0.5,0.75,1,2,4$, and $6 \mathrm{~h}$ after injection, $250 \mu \mathrm{L}$ of blood was taken through retroorbital sinus vein using heparinized capillary without anesthesia from each rat and centrifuged by heparinized microtube at 5,000 rpm for 5 minutes. One hundred $\mu \mathrm{L}$ of plasma was transferred into a clean glass test tube and thereafter $10 \mu \mathrm{L}$ IS with a concentration of $15 \mu \mathrm{g} / \mathrm{mL}$ was added. Plasma was extracted using the LLE method described before. Fifty $\mu \mathrm{L}$ of the final reconstituted solution was injected into the injection port of the HPLC system. By comparing the ratio obtained from the standard curve and peak area ratio of docetaxel or celecoxib to internal standard from samples, docetaxel, and celecoxib concentrations were determined.

\section{Pharmacokinetic analysis}

Plasma concentration-time data were fitted in a twocompartment open model $\mathrm{C}_{\mathrm{t}}=\mathrm{Ae}^{-\alpha \mathrm{t}}+\mathrm{Be}^{-\beta \mathrm{t}}$, where, $\mathrm{C}_{\mathrm{t}}$ is the drug concentration at time $\mathrm{t}$; $\mathrm{A}$ is residual intercept and $\mathrm{B}$ is the intercept of an ordinate axis, and $\alpha$ and $\beta$ are the corresponding first-order disposition rate constants. Finally, pharmacokinetic parameters including the area under the plasma concentrationtime curve from zero to infinity $\left(\mathrm{AUC}_{0-\infty}\right)$, the apparent volume of distribution $\left(\mathrm{V}_{\mathrm{d}}\right)$, systemic plasma clearance (CL), distribution half-life $\left(\mathrm{T}_{1 / 2 \alpha}\right)$, elimination half-life $\left(\mathrm{T}_{1 / 2 \beta}\right)$ and mean residence time (MRT) were calculated by standard methods.

\section{RESULTS}

\section{Determination of UV wavelength}

In order to acquire appropriate UV wavelength for simultaneous verification, solutions of docetaxel, celecoxib, and paclitaxel in the mobile phase were scanned by UV spectroscopy in the range of 200-400 $\mathrm{nm}$. Three tested compounds jointly have considerable absorbance at $230 \mathrm{~nm}$.

\section{Selection of appropriate extracting solvent and internal standard}

In order to achieve suitable internal standard several compounds such as flutamide, diazepam, paclitaxel, budesonide, and dexamethasone with similar lipophilicity and UV absorptivity to docetaxel and celecoxib were tested. Flutamide (Fig. 1b) and diazepam traces appeared adjacent to the docetaxel peak showing a double peaks pattern. Budesonide (Fig. 1c), dexamethasone (Fig. 1d), and paclitaxel (Fig. 1e) were considered appropriate internal standards with no interferences with plasma endogenous materials once diethyl ether was used as the extracting solvent, however, a late eluting peak at $40 \mathrm{~min}$ was observed (Fig. 1f) resulting in unacceptable run time. Extraction of plasma, serum, pure water, and heparin with diethyl ether revealed that this late peak is most likely due to the plasma endogenous substances. PP prior to the extraction of plasma samples with diethyl ether not only could fully wipe off the late eluting peak but also dramatically reduced the drug extraction efficiency. Chloroform and n-hexane were examined separately to extract the analytes. With chloroform, the 40-min late peak was disappeared but another one appeared at $25 \mathrm{~min}$. With the use of n-hexane no further late peak was detected but docetaxel was not extracted efficiently.

Although budesonide (Fig. 1c) and dexamethasone (Fig. 1d) were completely resolved from the docetaxel peak, they interfered with endogenous plasma peaks when n-hexane:isoamyl alcohol (97:3) was used as an extracting solvent. Ultimately, paclitaxel was considered the most appropriate IS once n-hexane:isoamyl alcohol (97:3) was used as extracting solvent. The mixture of $n$ hexane:isoamyl alcohol resulted in no late eluting peaks and significant recovery of analytes.

\section{Selectivity and specificity}

The HPLC chromatograms recorded for the blank dissolution (Fig. 2) revealed almost no peaks during the run time and all substances were eluted completely and appeared as separate resolved peaks. Representative chromatograms show a clear separation of docetaxel and celecoxib in a poloxamer $1.5 \% \mathrm{~W} / \mathrm{V}$ solution, which was used as the external phase for the preparation of the microspheres. Figure 3 shows typical chromatograms of blank plasma and plasma spiked with docetaxel, celecoxib, and paclitaxel. As illustrated, three substances eluted with good resolution as three separate resolved peaks within $20 \mathrm{~min}$. Initial peaks related to the plasma matrix appeared up to $10 \mathrm{~min}$, which did not interfere with the analyte peaks. Docetaxel, paclitaxel, and celecoxib eluted at 10.9, 12.4, and $16.8 \mathrm{~min}$, respectively. Table 1 displays the peak factors of docetaxel and celecoxib with their adjacent peaks. Hence, the presented method is selective for the simultaneous determination of docetaxel and celecoxib. 


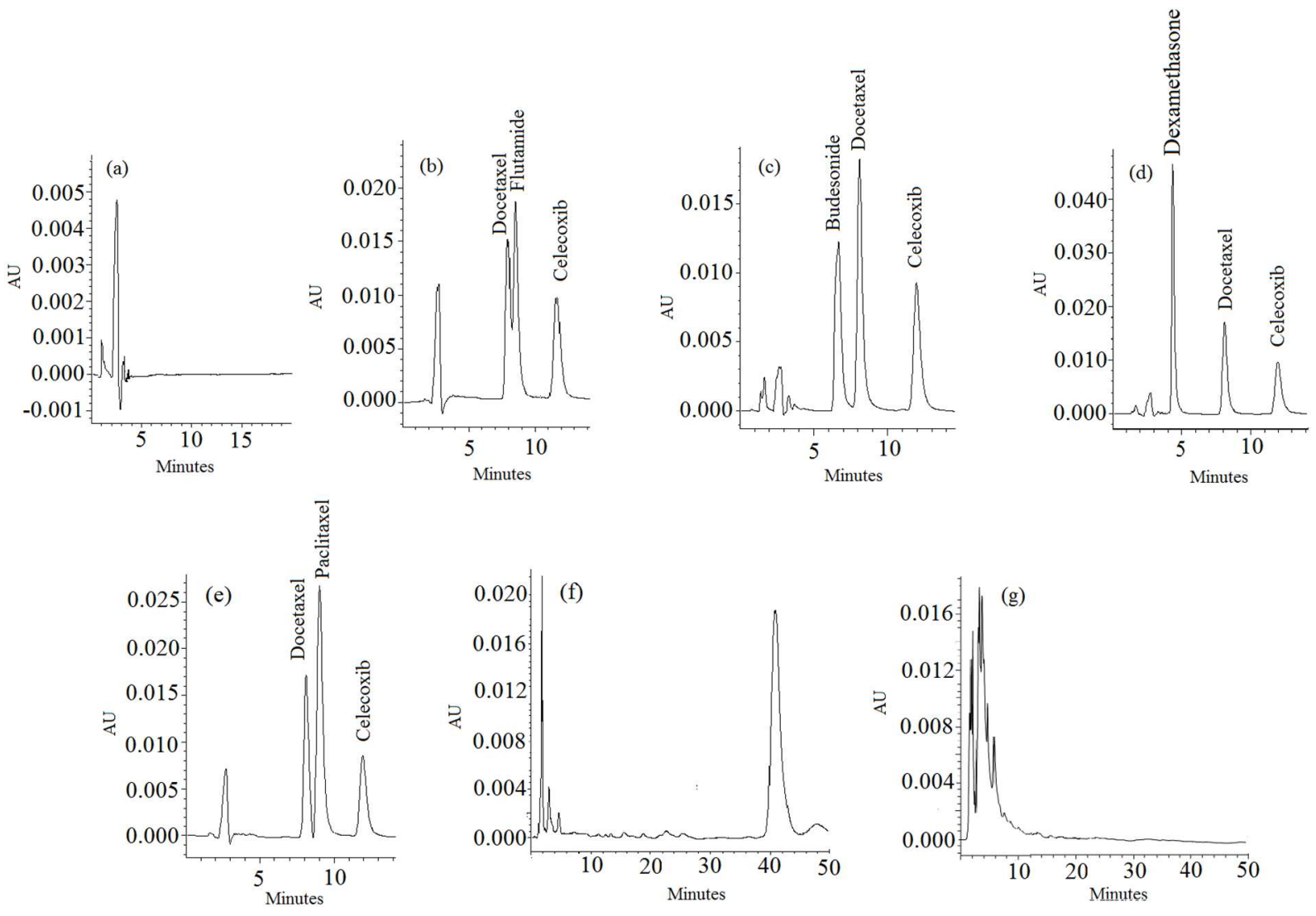

Figure 1. HPLC chromatograms of blank dissolution medium (a), docetaxel $(10 \mu \mathrm{g} / \mathrm{mL})$ and celecoxib $(3 \mu \mathrm{g} / \mathrm{mL})$ with different internal standards $(10 \mu \mathrm{g} / \mathrm{mL})$. Flutamide (b), budesonide (c), dexamethasone (d), paclitaxel (e), 45-min eluting peak (f), blank plasma samples extracted with diethyl ether (f), and blank plasma samples extracted with n-hexane:isoamyl alcohol (g) eluted with acetonitrile:water (50:50).
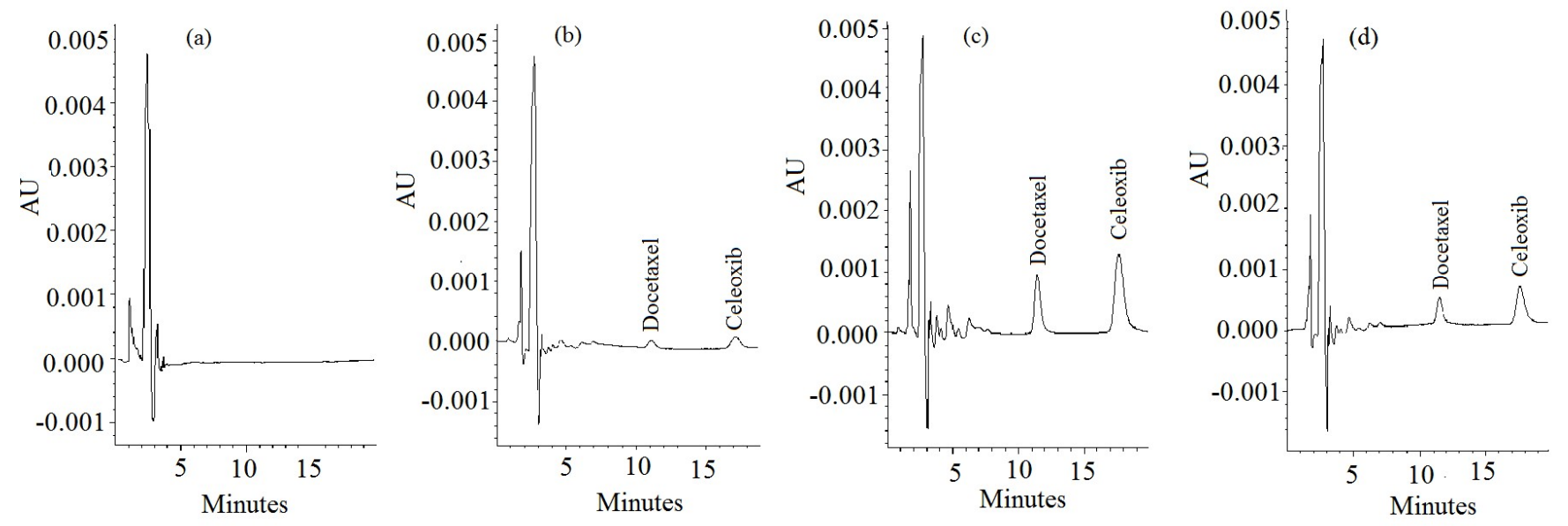

Figure 2. HPLC chromatograms of blank dissolution medium (a), dissolution medium containing $0.1 \mu \mathrm{g} / \mathrm{mL}$ docetaxel and celecoxib (b), dissolution medium containing $1 \mu \mathrm{g} / \mathrm{mL}$ docetaxel and celecoxib (c), and docetaxel and celecoxib released from porous particles in dissolution experiment after $36 \mathrm{~h}(\mathrm{~d})$. 

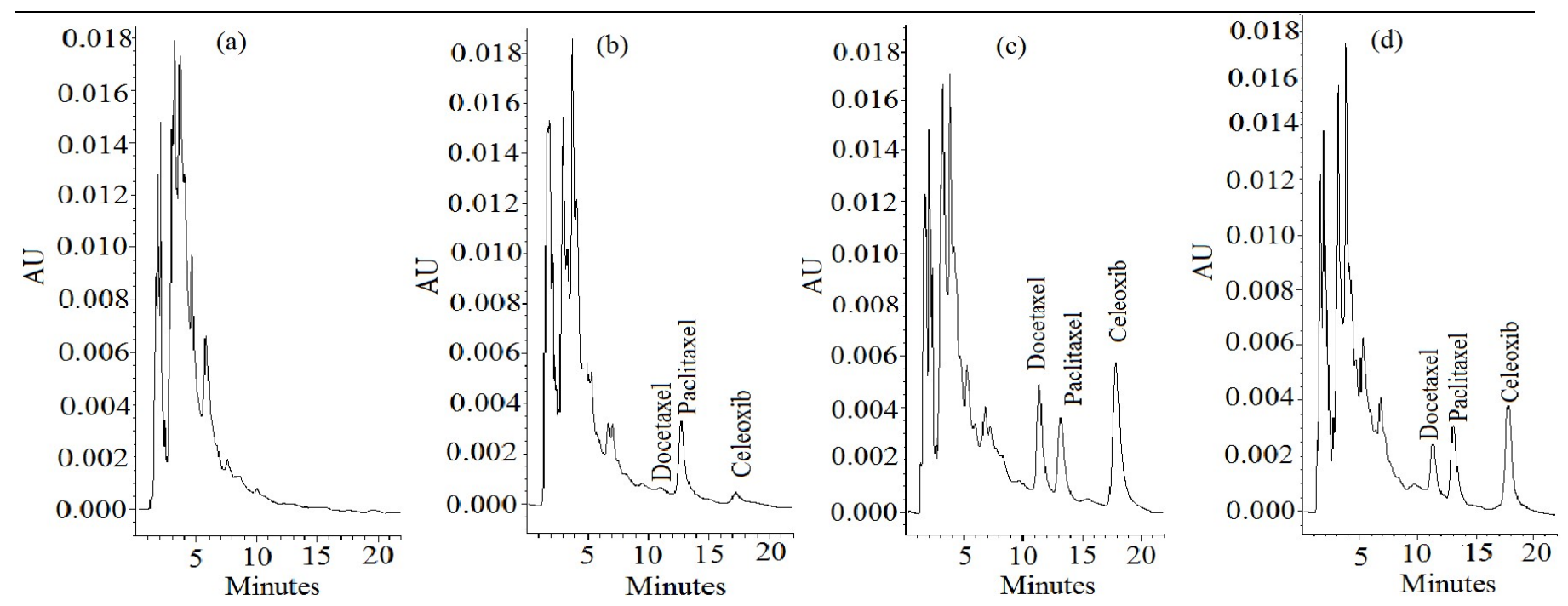

Figure 3. HPLC chromatograms of blank plasma extracted with n-hexane:isoamyl alcohol (97:3) (a), plasma contained 0.05 $\mu \mathrm{g} / \mathrm{mL}$ docetaxel and celecoxib (b), plasma contained $3 \mu \mathrm{g} / \mathrm{mL}$ docetaxel and celecoxib (c), and plasma taken from rat 30 min after IV bolus injection of $5 \mathrm{mg} / \mathrm{kg}$ docetaxel along with $5 \mathrm{mg} / \mathrm{kg}$ celecoxib (d).

Table 1. docetaxel and celecoxib peaks related parameters

\begin{tabular}{|c|c|c|c|c|c|c|c|c|c|c|c|c|c|}
\hline \multicolumn{3}{|c|}{ Tailing factor } & \multicolumn{4}{|c|}{ Resolution factor } & \multicolumn{3}{|c|}{ Retention time } & \multicolumn{2}{|c|}{ Peak area ratio } & \multicolumn{2}{|c|}{ Accuracy } \\
\hline DTX & PTX & CXB & $\begin{array}{l}\text { Plasma- } \\
\text { DTX }\end{array}$ & $\begin{array}{l}\text { DTX- } \\
\text { PTX }\end{array}$ & $\begin{array}{l}\text { PTX- } \\
\text { CXB }\end{array}$ & $\begin{array}{l}\text { DTX- } \\
\text { CXB }\end{array}$ & DTX & PTX & $\mathrm{CXB}$ & DTX & CXB & DTX & CXB \\
\hline 1.07 & 1.16 & 1.20 & 1.22 & 1.80 & 6.59 & 4.65 & 10.9 & 12.4 & 16.81 & 0.61 & 1.31 & 1.05 & 0.39 \\
\hline
\end{tabular}

\section{Calibration curves and linearity}

Calibration curves for docetaxel and celecoxib were plotted in dissolution medium and plasma as described before. As shown in Fig. 4, the developed method demonstrated excellent linearity for docetaxel and celecoxib for both dissolution and pharmacokinetic studies as indicated with mean correlation coefficients $>0.999$. The regression equations are shown in Fig. 4 (a) and (b).
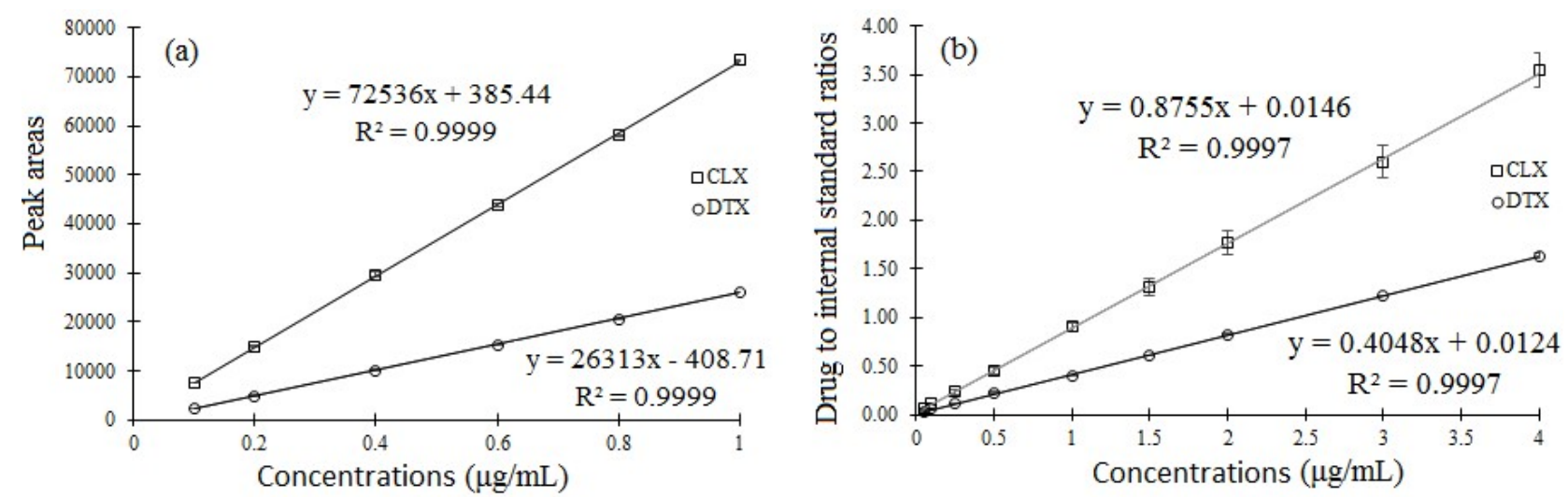

Figure 4. Calibration curves of docetaxel and celecoxib in: dissolution medium (a), plasma (b). Each point represents means \pm $\mathrm{SD}(\mathrm{n}=3)$. Due to small variations amongst experiments, in many data points, particularly in dissolution medium test, SD bars are not visible. 
Precision, accuracy and recovery

Results attained for precision and accuracy studies of the method in dissolution medium and plasma specimens are presented in Table 2 and Table 3, respectively. All results comply with the acceptance criteria defined in the International Conference on
Harmonization (ICH) guidelines showing well precision and accuracy of the method. Table 4 shows the percent recoveries of docetaxel, celecoxib, and paclitaxel in plasma at three concentrations of quality control i.e. low, medium, and high.

Table 2. Intra- and inter-day precision and accuracy of the HPLC method developed for determination of docetaxel and celecoxib in dissolution medium

\begin{tabular}{|c|c|c|c|c|c|c|c|c|c|}
\hline & & & a-day pr & cision and ac & uracy & & r-day pre & ision and acc & Iracy \\
\hline & $\begin{array}{c}\text { Concentration } \\
(\mu \mathrm{g} / \mathrm{mL})\end{array}$ & Mean & S.D. & $\begin{array}{c}\text { R.S.D. } \\
\text { (Precision) }\end{array}$ & $\begin{array}{c}\text { Accuracy } \\
(\%)\end{array}$ & Mean & S.D. & $\begin{array}{c}\text { R.S.D. } \\
\text { (Precision) }\end{array}$ & $\begin{array}{c}\text { Accuracy } \\
(\%)\end{array}$ \\
\hline & 0.1 & 0.101 & 0.0015 & 1.43 & 101.3 & 0.101 & 0.0014 & 1.41 & 101.3 \\
\hline & 0.2 & 0.201 & 0.0031 & 1.54 & 100.5 & 0.201 & 0.0026 & 1.28 & 100.4 \\
\hline 芜 & 0.4 & 0.399 & 0.0033 & 0.82 & 99.84 & 0.400 & 0.0030 & 0.75 & 100.0 \\
\hline ষ্ঠ & 0.6 & 0.596 & 0.0037 & 0.62 & 99.41 & 0.596 & 0.0034 & 0.58 & 99.33 \\
\hline 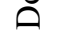 & 0.8 & 0.798 & 0.0052 & 0.66 & 99.76 & 0.798 & 0.0051 & 0.63 & 99.76 \\
\hline & 1.0 & 1.003 & 0.0045 & 0.45 & 100.3 & 1.004 & 0.0039 & 0.39 & 100.3 \\
\hline & 0.1 & 0.099 & 0.0007 & 0.72 & 99.44 & 0.100 & 0.0007 & 0.66 & 100.0 \\
\hline$?$ & 0.2 & 0.200 & 0.0015 & 0.77 & 100.1 & 0.200 & 0.0017 & 0.85 & 100.1 \\
\hline$\stackrel{\star}{\circ}$ & 0.4 & 0.404 & 0.0070 & 1.73 & 100.8 & 0.403 & 0.0058 & 1.45 & 100.7 \\
\hline$\frac{0}{2}$ & 0.6 & 0.598 & 0.0023 & 0.38 & 99.70 & 0.598 & 0.0038 & 0.63 & 99.58 \\
\hline$\tilde{U}$ & 0.8 & 0.794 & 0.0017 & 0.22 & 99.22 & 0.794 & 0.0015 & 0.19 & 99.27 \\
\hline & 1.0 & 1.005 & 0.0026 & 0.25 & 100.4 & 1.005 & 0.0031 & 0.30 & 100.4 \\
\hline
\end{tabular}

Table 3. Intra and inter-day precision and accuracy of the HPLC method for determination of docetaxel and celecoxib in plasma

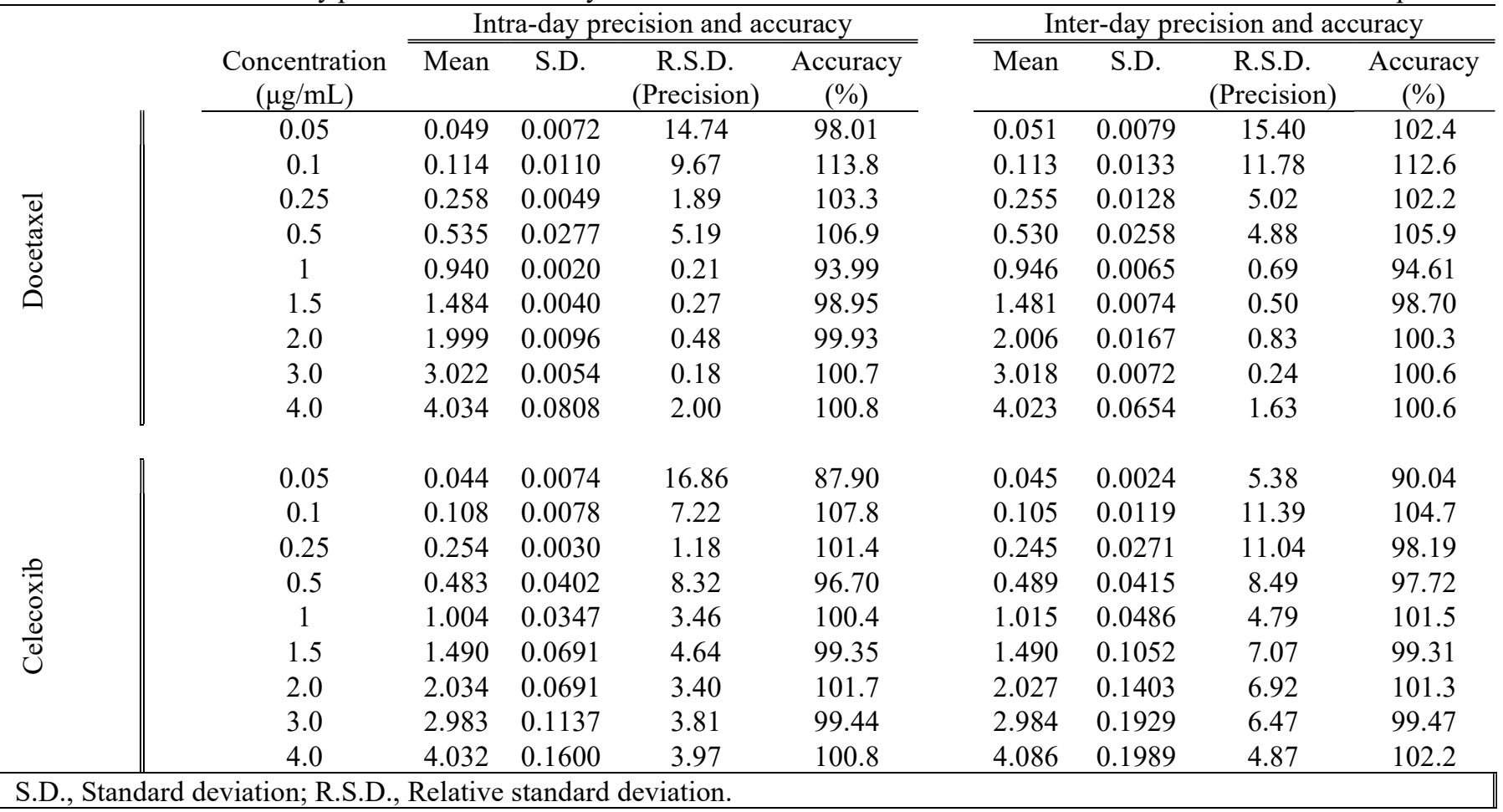


Table 4. Percent recoveries of docetaxel, celecoxib, and paclitaxel extracted from plasma $(n=3)$ with $n$-hexane:isoamyl alcohol (97:3) at three different concentrations

\begin{tabular}{cccc}
\hline & & Recovery $(\%)$ & \\
\hline $\begin{array}{c}\text { Concentration } \\
(\mu \mathrm{g} / \mathrm{mL})\end{array}$ & Docetaxel & Celecoxib & Paclitaxel (IS) \\
\hline 0.05 & $87.98 \pm 1.86$ & $92.45 \pm 1.89$ & - \\
1.5 & $84.20 \pm 0.72$ & $89.57 \pm 1.55$ & $78.36 \pm 0.24$ \\
3 & $77.91 \pm 0.95$ & $85.20 \pm 0.91$ & - \\
\hline
\end{tabular}

\section{Limit of detection (LOD) and limit of quantitation (LOQ)}

The LOD and LOQ for docetaxel and celecoxib in dissolution medium were $0.05 \mu \mathrm{g} / \mathrm{mL}$ and $0.1 \mu \mathrm{g} / \mathrm{mL}$, respectively. The LOD for docetaxel and celecoxib in plasma was approximately $0.01 \mu \mathrm{g} / \mathrm{mL}$. The LOQ of docetaxel and celecoxib corresponding to a coefficient of variation of less than $15 \%$ was $0.05 \mu \mathrm{g} / \mathrm{mL}$ once 100 $\mu \mathrm{L}$ of the plasma sample was extracted, dried, reconstituted in $100 \mu \mathrm{L}$ of the mobile phase of which $50 \mu \mathrm{L}$ was injected into the HPLC system.

\section{Robustness}

Fig. 5 illustrates the robustness data of the assay method. It shows the percent changes in retention time, tailing factor, resolution factor, peak area ratio, and accuracy compared to the set-up method parameters listed in Table 1. Method robustness was checked after deliberate modifications in the mobile phase composition, flow rate, and $\mathrm{pH}$.

\section{in vitro and in vivo application of the method}

The method described here was successfully applied for simultaneous quantification of docetaxel and celecoxib in dissolution studies of docetaxel- and celecoxib-containing porous microparticles, and pharmacokinetic study using rat plasma. Fig. 6a illustrates the dissolution profiles of docetaxel and celecoxib released from microparticles and Fig. $6 \mathrm{~b}$ shows the concentration-time profiles of docetaxel and celecoxib following IV administration of $5 \mathrm{mg} / \mathrm{kg}$ docetaxel and $5 \mathrm{mg} / \mathrm{kg}$ celecoxib. Table 5 includes pharmacokinetic parameters.

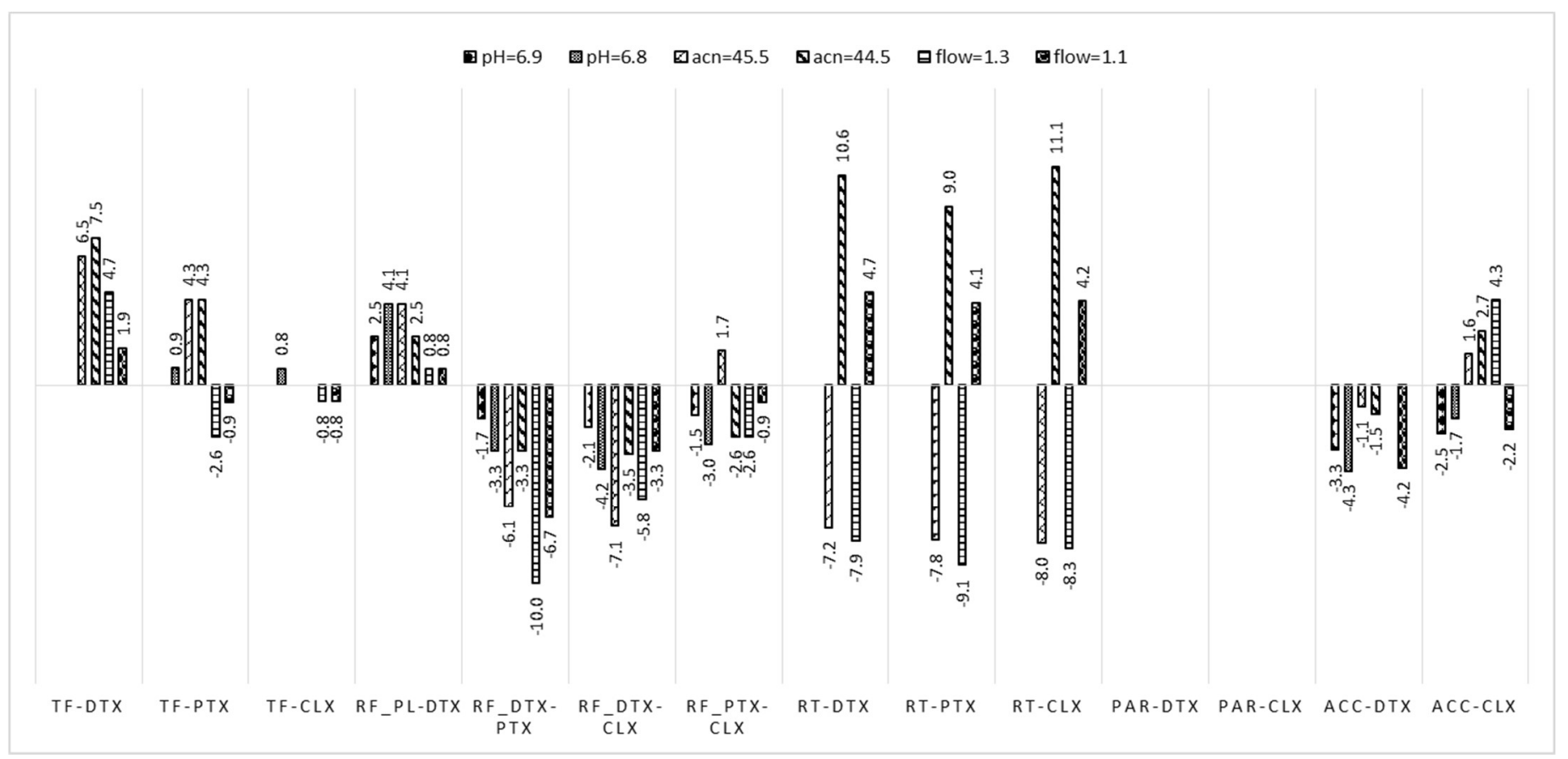

Figure 5. Robustness result of the assay method. It shows the percent changes in retention time (RT), tailing factor (TF), resolution factor (RF), peak area ratio (PAR), and accuracy (ACC) compared with set-up method parameters mentioned in Table 1. DTX, Docetaxel; CXB, Celecoxib; PL, Plasma. 

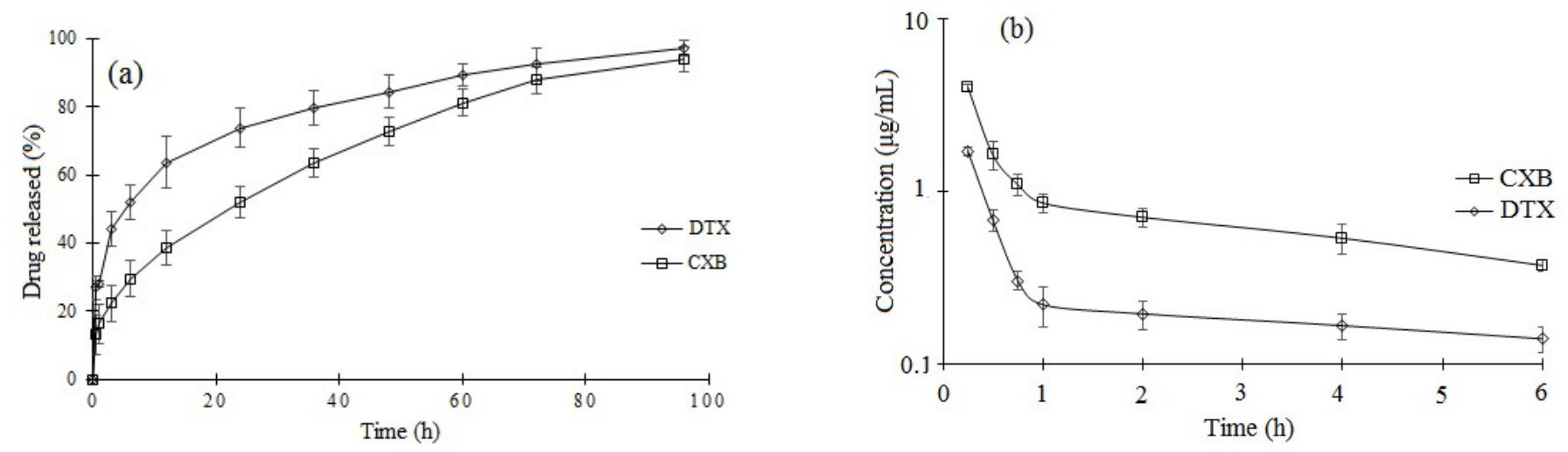

Figure 6. Release profiles of docetaxel and celecoxib liberated from porous microparticles (a), and concentration-time profiles of docetaxel and celecoxib fallowing IV administration of $5 \mathrm{mg} / \mathrm{kg}$ of docetaxel and celecoxib $(\mathrm{b})(\mathrm{n}=3)$.

Table 5. The plasma pharmacokinetic parameters of docetaxel and celecoxib $(n=3)$

\begin{tabular}{|c|c|c|c|c|c|c|c|c|c|c|c|}
\hline & $\begin{array}{c}\mathrm{AUC}_{0-\infty} \\
\left(\mathrm{mg} . \mathrm{h} . \mathrm{L}^{-1}\right) \\
\end{array}$ & $\begin{array}{l}\text { AUMC }_{0-\infty} \\
\left(\mathrm{mg} \cdot \mathrm{L}^{-1}\right) \cdot \mathrm{h}^{2} \\
\end{array}$ & $\begin{array}{c}\text { CLTB } \\
\text { L. }\left(\text { h.kg) }{ }^{-1}\right. \\
\end{array}$ & $\begin{array}{c}\text { MRT } \\
(\mathrm{h}) \\
\end{array}$ & $\begin{array}{c}\mathrm{V}_{\mathrm{dss}} \\
\left(\mathrm{L} \mathrm{kg}^{-1}\right) \\
\end{array}$ & $\begin{array}{c}\mathrm{A} \\
\left(\mathrm{mg} \cdot \mathrm{L}^{-1}\right) \\
\end{array}$ & $\begin{array}{c}\mathrm{a} \\
\left(\mathrm{h}^{-1}\right) \\
\end{array}$ & $\begin{array}{c}\mathrm{T}_{1 / 2 \mathrm{a}} \\
(\mathrm{h}) \\
\end{array}$ & $\begin{array}{c}\mathrm{B} \\
\left(\mathrm{mg} \cdot \mathrm{L}^{-1}\right) \\
\end{array}$ & $\begin{array}{c}\beta \\
\left(\mathrm{h}^{-1}\right) \\
\end{array}$ & $\begin{array}{l}\mathrm{T}_{1 / 2 \beta} \\
(\mathrm{h}) \\
\end{array}$ \\
\hline Docetaxel & $\begin{array}{c}3.91 \\
\pm 0.17\end{array}$ & $\begin{array}{r}32.39 \\
\pm 4.43\end{array}$ & $\begin{array}{c}1.28 \\
\pm 0.06\end{array}$ & $\begin{array}{c}8.29 \\
\pm 1.19\end{array}$ & $\begin{array}{r}10.62 \\
\pm 1.75\end{array}$ & $\begin{array}{c}6.79 \\
\pm 0.20\end{array}$ & $\begin{array}{c}5.80 \\
\pm 0.27\end{array}$ & $\begin{array}{c}0.12 \\
\pm 0.01\end{array}$ & $\begin{array}{c}0.24 \\
\pm 0.06\end{array}$ & $\begin{array}{c}0.09 \\
\pm 0.02\end{array}$ & $\begin{array}{c}8.20 \\
\pm 1.46\end{array}$ \\
\hline Celecoxib & $\begin{array}{c}8.20 \\
\pm 0.74\end{array}$ & $\begin{array}{l}38.11 \\
\pm 3.85\end{array}$ & $\begin{array}{c}0.61 \\
\pm 0.06\end{array}$ & $\begin{array}{c}4.65 \\
\pm 0.09\end{array}$ & $\begin{array}{c}2.85 \\
\pm 0.23\end{array}$ & $\begin{array}{l}11.06 \\
\pm 0.83\end{array}$ & $\begin{array}{c}5.38 \\
\pm 0.39\end{array}$ & $\begin{array}{c}0.13 \\
\pm 0.01\end{array}$ & $\begin{array}{c}1.00 \\
\pm 0.14\end{array}$ & 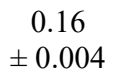 & $\begin{array}{c}4.26 \\
\pm 0.09\end{array}$ \\
\hline
\end{tabular}

AUC, Area under the zero-moment curve; AUMC, Area under the first moment curves; CL ${ }_{\mathrm{TB}}$, Total body clearance; MRT, Mean residence time; $\mathrm{V}_{\mathrm{dss}}$, Volume of distribution; $\mathrm{T}_{1 / 2} \mathrm{a}$, Distribution half-life; $\mathrm{T}_{1 / 2 \beta}$, Elimination half-life.

\section{DISCUSSION}

In the current study, our purpose was to develop a simple, sensitive, and reliable HPLC method for simultaneous determination of docetaxel and celecoxib, which can be applied both in in vitro (dissolution characterization) and in vivo (pharmacokinetics studies) assessment of porous microparticles developed in our laboratory and loaded with these two drugs. Dissolution is a characterization test used to guide the formulation and is the only test that measures the rate of drug release in vitro as a function of time, which predicts drug release in vivo. As illustrated, three substances docetaxel, paclitaxel, and celecoxib eluted as sharp symmetrical peaks at $10.9,12.4$, and $16.8 \mathrm{~min}$, respectively, and overall separation run time lasted $20 \mathrm{~min}$ and thereafter the system was ready for the next injection. The small peaks related to the plasma matrix appeared in the first $10 \mathrm{~min}$ and did not interfere with the analyte peaks. Three substances were eluted completely without peak tailing indicating that the assay method involves high specificity and selectivity from endogenous substances and other associated agents. The precision (repeatability) and accuracy of the calibration standard concentrations for both dissolution medium and plasma specimens were within the acceptable limits as defined in the ICH guidelines indicating that the developed method is precise, accurate, and reproducible for measuring docetaxel and celecoxib.

The method robustness referring to the ability of the assay to remain unaffected by small but deliberate changes to chromatographic conditions provides an indication of its reliability during routine usage (59). The robustness of the method checked after deliberate alterations of the mobile phase composition, mobile phase $\mathrm{pH}$ and flow rate, showed that the changes of the operational parameters did not lead to any essential changes in the performance of the chromatographic system. The tailing factor for docetaxel, celecoxib, and paclitaxel always ranged from 1.0 to 1.2 , and drugs were well separated under all the changes carried out. The accuracy of docetaxel and celecoxib was acceptable under most conditions and did not show significant changes when the critical parameters were altered. Considering the result of alterations in the system suitability parameters and the specificity of the method, it would be concluded that the method conditions are robust. The percent recoveries of docetaxel and celecoxib were desirable under most 
conditions and did not show a significant change when the critical parameters were altered.

To extract docetaxel and celecoxib from plasma samples, most of analytical methods have made the use of multiple steps LLE, SPE or PP followed by evaporation to prepare and concentrate samples prior to injection into the HPLC column. UV-HPLC assay based on PP with acetonitrile for quantification of docetaxel and celecoxib in plasma have been reported. PP has resulted in higher LOQ for DTX $(3.1 \mu \mathrm{g} / \mathrm{mL})$ (60) which is much greater than the value accomplished in our study $(0.05 \mu \mathrm{g} / \mathrm{mL})$ making the assay not applicable to a very low volume of plasma taken from small animals. Sample preparation involved PP for celecoxib used 1:1 ratio of acetonitrile to plasma to avoid dilution of the sample and to prevent the reduction in the sensitivity of the assay but this may lead to inadequate precipitation of the protein contents in the samples and deterioration of the chromatographic column in the long run $(49,61)$. In our study, PP with acetonitrile was tested and percent recovery of docetaxel and celecoxib decreased dramatically.

Solid phase extraction technique for drug extraction and sample cleanup has been considered as a more efficient approach for increasing method sensitivity. PP followed by SPE also used to quantify docetaxel in rabbit plasma, which exhibited a LOQ 10 $\mathrm{ng} / \mathrm{mL}$ (62), removed the interfering substances, and offered good extraction recoveries of docetaxel. However, most HPLC assays for docetaxel determination in biological fluids using the SPE cleanup method (63-66) required a large volume of samples (1-4 $\mathrm{mL})$ and long eluting run times. In the method of Stormer (67) for determination of celecoxib, PP with acetonitrile, evaporation of the organic phase to dryness, and dissolution of the residue in water prior to SPE make the extraction procedure difficult. Rose et al (68) used more costly normal phase HPLC in which PP was used prior to SPE.

To circumvent the aforementioned limitations, we developed and validated a sensitive and reliable HPLC method for the simultaneous determination of docetaxel and celecoxib following single-step LLE and UV detection. In this context, the isocratic RPHPLC method with LLE and UV detection for analysis of docetaxel in rat plasma and tissues (42) and celecoxib in human plasma (48) we have already proposed were also considered.

One of the specific features of the present HPLC assay is one-step efficient LLE of docetaxel, celecoxib, and paclitaxel from plasma making the method more convenient for pharmacokinetic studies of these drugs. Amongst different extracting solvents examined in the preliminary evaluation as outlined in "selection of appropriate extracting solvent and internal standard" section, a mixture of n-hexane and isoamyl alcohol (97:3) employed, and HPLC was performed isocratically on a reversed-phase column with UV detection. The extraction procedure of this assay is economical and convenient with good extraction efficiency as determined by comparison of the peak areas of the spiked plasma samples with those of un-extracted docetaxel or celecoxib solution. The recoveries were consistent for the samples as demonstrated by very low standard deviations. Recoveries were not dependent on the plasma concentrations, which consequently resulted in good linearity of the calibration curve. Good linear relationships were found when the peak area ratios of docetaxel or celecoxib to the internal standard were plotted versus the plasma concentrations. In the present work, paclitaxel met all typical requirements as an appropriate IS. This agent is stable during the analysis, readily available, and well-resolved from docetaxel and celecoxib. The use of IS increases the accuracy and precision of the assay.

To achieve the highest resolution, sensitivity, and elution under an isocratic condition, the mixtures of acetonitrile with various proportions of water were assessed as the mobile phase. A binary mixture of water/acetonitrile at 55:45 (v/v) proved to be the most effective combination as evidenced by more efficient resolution, lack of tailing, noiseless baseline, and satisfactory retention and run times. The gradient mode has already been used to resolve docetaxel peak from that of IS; where the composition of the mobile phase should be continuously changed throughout the run (69) making the method more complex and not sufficiently reproducible compared to isocratic methods. The LOQ of the present assay for docetaxel and celecoxib in in vitro and in vivo studies is adequate for pharmacokinetic characterization of tested drugs in small animals from whom limited volumes of plasma could be taken at each time point.

The docetaxel and celecoxib plasma concentration versus time exhibited a biexponential plot demonstrating a two-compartment open model with a distribution phase followed by an elimination phase. The calculated pharmacokinetic values given in Table 5 are in line with the results of previous studies for celecoxib (45); however, some pharmacokinetic parameters including $\mathrm{AUC}_{0-\infty}$, systemic clearance, and 
distribution volume for docetaxel are similar to those reported by Luo et al (70).

\section{CONCLUSION}

The present investigation describes an HPLC method using UV detection for the simultaneous analysis of docetaxel and celecoxib in plasma with LLE of drugs and IS from plasma specimens and for in vitro characterization of formulations. The method was validated and met the requirements of selectivity, linearity, recovery, accuracy, precision, and robustness. This validated method was successfully used to quantify docetaxel and celecoxib simultaneously in the release of the drugs from microparticles and pharmacokinetic studies. nhexane:isoamyl alcohol (97:3) mixture as the extracting solvent resulted in a highly efficient recovery of the drugs from plasma samples. Since docetaxel and celecoxib will be co-administered for the treatment of a wide range of cancers such as NSCLC, the developed method has a great potential for routine therapeutic drug monitoring of these two drugs.

\section{ACKNOWLEDGMENTS}

The content of this paper is extracted from the Pharm.D. thesis No. 297144 submitted by E. Ziaei who was financially supported by the Research Department of Isfahan University of Medical Sciences, Isfahan, Iran.

\section{REFERENCES}

1. Whitehead CM, Earle KA, Fetter J, Xu S, Hartman T, Chan DC, et al. Exisulind-induced apoptosis in a nonsmall cell lung cancer orthotopic lung tumor model augments docetaxel treatment and contributes to increased survival. Mol Cancer Ther, 2003; 2(5):47988.

2. Shaik MS, Chatterjee A, Jackson T, Singh M. Enhancement of antitumor activity of docetaxel by celecoxib in lung tumors. Int J Cancer, 2006; 118(2):396-404. DOI: 10.1002/ijc.21325.

3. Marchettini P, Stuart OA, Mohamed F, Yoo D, Sugarbaker PH. Docetaxel: pharmacokinetics and tissue levels after intraperitoneal and intravenous administration in a rat model. Cancer Chemother Pharmacol, 2002; 49(6):499-503. DOI: 10.1007/s00280-002-0439-1.

4. Zhao M, Su M, Lin X, Luo Y, He H, Cai C, Tang X. Evaluation of docetaxel-loaded intravenous lipid emulsion: pharmacokinetics, tissue distribution, antitumor activity, safety and toxicity. Pharm Res, 2010; 27(8):1682-702. DOI: 10.1007/s11095-010$0180-0$.

5. Huang Q, Wang GJ, Sun JG, Hu Xl, Lu YH, Zhang Q. Simultaneous determination of docetaxel and ketoconazole in rat plasma by liquid chromatography/electrospray ionization tandem mass spectrometry. Rapid Commun Mass Spectrom, 2007; 21(6):1009-18. DOI: 10.1002/rcm.2903.

6. McGrogan BT, Gilmartin B, Carney DN, McCann A. Taxanes, microtubules and chemoresistant breast cancer. Biochim Biophys Acta, 2008; 1785(2):96-132. DOI: 10.1016/j.bbcan.2007.10.004.

7. Rowinsky EK. The development and clinical utility of the taxane class of antimicrotubule chemotherapy agents. Annu Rev Med, 1997; 48:353-74. DOI: 10.1146/annurev.med.48.1.353.

8. Kargman SL, O'Neill Gp, Vickers PJ, Evans JF, Mancini JA, Jothy S. Expression of prostaglandin G/H synthase- 1 and -2 protein in human colon cancer. Cancer Res, 1995; 55(12):2556-9.

9. Liu XH, Rose DP. Differential expression and regulation of cyclooxygenase- 1 and -2 in two human breast cancer cell lines. Cancer Res, 1996; 56(22):5125-7.

10. Muller-Decker K, Fürstenberger G. The cyclooxygenase-2-mediated prostaglandin signaling is causally related to epithelial carcinogenesis. Mol Carcinog, 2007; 46(8):705-10. DOI: 10.1002/mc. 20326.

11. Ristimaki A, Honkanen N, Jankala H, Sipponen P, Harkonen M. Expression of cyclooxygenase-2 in human gastric carcinoma. Cancer Res, 1997; 57(7):1276-80.

12. Deininger MH, Weller M, Streffer J, Mittelbronn M, Meyermann R. Patterns of cyclooxygenase- 1 and -2 expression in human gliomas in vivo. Acta Neuropathol, 1999; 98(3):240-4. DOI: $10.1007 / \mathrm{s} 004010051075$

13. Elder DJ, Halton De, Hague A, Paraskeva C. Induction of apoptotic cell death in human colorectal carcinoma cell lines by a cyclooxygenase-2 (COX-2)-selective nonsteroidal anti-inflammatory drug: independence from COX-2 protein expression. Clin Cancer Res, 1997; 3(10):1679-83.

14. Liu XH, Yao S, Kirschenbaum A, Levine AC. NS398, a selective cyclooxygenase-2 inhibitor, induces apoptosis and down-regulates bcl-2 expression in LNCaP cells. Cancer Res, 1998; 58(19):4245-9.

15. Molina MA, Sitja-Arnau M, Lemoine MG, Frazier ML, Sinicrope FA. Increased cyclooxygenase- 2 expression in human pancreatic carcinomas and cell lines: growth inhibition by nonsteroidal anti-inflammatory drugs. Cancer Res, 1999; 59(17):4356-62.

16. Tsujii M, Kawano S, Tsuji S, Sawaoka H, Hori M, DuBois RN. Cyclooxygenase regulates angiogenesis induced by colon cancer cells. Cell, 1998; 93(5):70516. DOI: $10.1016 / \mathrm{s} 0092-8674(00) 81433-6$. 
17. Wilson KT, Fu S, Ramanujam KS, Meltzer SJ. Increased expression of inducible nitric oxide synthase and cyclooxygenase-2 in Barrett's esophagus and associated adenocarcinomas. Cancer Res, 1998; 58(14):2929-34.

18. Wolff H, Saukkonen K, Anttila S, Karjalainen A, Vainio H, Ristimaki A. Expression of cyclooxygenase2 in human lung carcinoma. Cancer Res, 1998; 58(22):4997-5001.

19. Blaine SA, Wick M, Dessev C, Nemenoff RA. Induction of cPLA2 in lung epithelial cells and nonsmall cell lung cancer is mediated by Sp1 and c-Jun. $\mathrm{J}$ Biol Chem, 2001; 276(46):42737-43. DOI: 10.1074/jbc.M107773200.

20. Zweifel BS, Davis TW, Ornberg RL, Masferrer JL. Direct evidence for a role of cyclooxygenase 2-derived prostaglandin E2 in human head and neck xenograft tumors. Cancer Res, 2002; 62(22):6706-11.

21. Masferrer JL, Leahy KM, Koki AT, Zweifel BS, Settle SL, Woerner BM, Edwards DA, Flickinger AG, Moore RJ, Seibert K. Antiangiogenic and antitumor activities of cyclooxygenase-2 inhibitors. Cancer Res, 2000; 60(5):1306-11.

22. Shishodia S, Koul D, Aggarwal BB. Cyclooxygenase (COX)-2 inhibitor celecoxib abrogates TNF-induced NF-kappa B activation through inhibition of activation of I kappa B alpha kinase and Akt in human non-small cell lung carcinoma: correlation with suppression of COX-2 synthesis. J Immunol, 2004; 173(3):2011-22. DOI: 10.4049/jimmunol.173.3.2011.

23. Fulzele SV, Chatterjee A, Shaik MS, Jackson T, Singh M. Inhalation delivery and anti-tumor activity of celecoxib in human orthotopic non-small cell lung cancer xenograft model. Pharm Res, 2006; 23(9):20942106. DOI: 10.1007/s11095-006-9074-6.

24. Schneider BJ, Kalemkerian Gp, Kraut MJ, Wozniak AJ, Worden FP, Smith DW, Chen W, Gadgeel SM. Phase II study of celecoxib and docetaxel in non-small cell lung cancer (NSCLC) patients with progression after platinum-based therapy. J Thorac Oncol, 2008; 3(12):1454-9. DOI: 10.1097/JTO.0b013e31818de1d2.

25. Takhar HA-Ohoo, Singhal N, Mislang A, Kumar R, Kim L, Selva-Nayagam S, et al. Phase II study of celecoxib with docetaxel chemoradiotherapy followed by consolidation chemotherapy docetaxel plus cisplatin with maintenance celecoxib in inoperable stage III nonsmall cell lung cancer. Asia Pac J Clin Oncol, 2018; 14(1):91-100. DOI: 10.1111/ajco.12749.

26. Alipour S, Montaseri H, Tafaghodi M. Preparation and characterization of biodegradable paclitaxel loaded alginate microparticles for pulmonary delivery. Colloids Surf B Biointerfaces, 2010; 81(2):521-9. DOI: 10.1016/j.colsurfb.2010.07.050.

27. Al-Qadi S, Grenha A, Remuñán-López C. Microspheres loaded with polysaccharide nanoparticles for pulmonary delivery: Preparation, structure and surface analysis. Carbohyd Polym, 2011; 86(1):25-34. DOI: 10.1016/j.carbpol.2011.03.022.
28. Taratula O, Kuzmov A, Shah M, Garbuzenko OB, Minko T. Nanostructured lipid carriers as multifunctional nanomedicine platform for pulmonary co-delivery of anticancer drugs and siRNA, J Control Release, 2013; 171(3):349-57. DOI: 10.1016/j.jconrel.2013.04.018.

29. Oh YJ, Lee J, Seo JY, Rhim T, Kim S-H, Yoon HJ, Lee KY. Preparation of budesonide-loaded porous PLGA microparticles and their therapeutic efficacy in a murine asthma model. J Controlled Release, 2011; 150(1):56-62. DOI: 10.1016/j.jconrel.2010.11.001.

30. Feng T, Tian H, Xu C, Lin L, Xie Z, Lam MH, Liang $\mathrm{H}$, Chen X. Synergistic co-delivery of doxorubicin and paclitaxel by porous PLGA microspheres for pulmonary inhalation treatment. Eur J Pharm Biopharm, 2014; 88(3):1086-93. DOI: 10.1016/j.ejpb.2014.09.012.

31. Saha RN1, Sajeev C, Jadhav PR, Patil SP, Srinivasan $N$. Determination of celecoxib in pharmaceutical formulations using UV spectrophotometry and liquid chromatography. J Pharm Biomed Anal, 2002; 28(34):741-51. DOI: 10.1016/s0731-7085(01)00678-1.

32. Attimarad M, Narayanswamy VK , Aldhubaib BE, SreeHarsha N, Nair AB. Development of UV spectrophotometry methods for concurrent quantification of amlodipine and celecoxib by manipulation of ratio spectra in pure and pharmaceutical formulation. PLoS One, 2019; 14(9):115, DOI: 10.1371/journal.pone.0222526.

33. Zhang L, Tan L, Chen L, Chen X, Long C, Peng J, Qian Z. A simple method to improve the stability of docetaxel micelles. Sci Rep, 2016; 6:1-10, DOI: 10.1038/srep36957.

34. Kuppens IE, Maanen MJ, Rosing H, Schellens JH, Beijnen JH. Quantitative analysis of docetaxel in human plasma using liquid chromatography coupled with tandem mass spectrometry. Biomed Chromatogr, 2005; 19(5):355-361. DOI: 10.1002/bmc.457.

35. Hou W, Watters JW, Mcleod HL. Simple and rapid docetaxel assay in plasma by protein precipitation and high-performance liquid chromatography-tandem mass spectrometry. J Chromatogr B Analyt Technol Biomed Life Sci, 2004; 804(2):263-267. DOI: 10.1016/j.jchromb.2004.01.021.

36. Parise RA, Ramanathan RK, Zamboni WC, Egorin MJ. Sensitive liquid chromatography-mass spectrometry assay for quantitation of docetaxel and paclitaxel in human plasma. J Chromatogr B Analyt Technol Biomed Life Sci, 2003; 783(1):231-236. DOI: 10.1016/s1570-0232(02)00659-1.

37. Kim DW, Yousaf AM, Li DX, Kim JO, Yong CS, Cho $\mathrm{KH}$, et al. Development of RP-HPLC method for simultaneous determination of docetaxel and curcumin in rat plasma: Validation and stability. Asian J Pharm Sci, 2017; 12(1):105-13. DOI: 10.1016/j.ajps.2016.08.002.

38. Taymouri S, Varshosaz J, Javanmard SH, Hassanzadeh F. Development of a rapid and precise reversed-phase 
high-performance liquid chromatography method for analysis of docetaxel in rat plasma: application in single-dose pharmacokinetic studies of folate-targeted micelles containing docetaxel. Adv Biomed Res, 2018; 7:76. DOI: $10.4103 / a b r . a b r ~ 25116$.

39. Garg MB, Ackland SP. Simple and sensitive highperformance liquid chromatography method for the determination of docetaxel in human plasma or urine. $\mathrm{J}$ Chromatogr B Biomed Sci Appl. 2000; 748(2):383388. DOI: 10.1016/s0378-4347(00)00356-x.

40. Andersen A, Warren DJ, Brunsvig P.F, Aamdal S, Kristensen GB, Olsen H. High sensitivity assays for docetaxel and paclitaxel in plasma using solid-phase extraction and high-performance liquid chromatography with UV detection. BMC Clin Pharmacol, 2006; 6:1-10, DOI: 10.1186/1472-6904-62.

41. Rouini MR, Lotfolahi A, Stewart DJ, Molepo JM, Shirazi FH, Vergniol JC, et al. A rapid reversed phase high performance liquid chromatographic method for the determination of docetaxel (Taxotere $\left.{ }^{\circledR}\right)$ in human plasma using a column switching technique. J Pharm Biomed Anal, 1998; 17:1243-7. DOI: 10.1016/s07317085(97)00233-1.

42. Kazemi M, Emami J, Hasanzadeh F, Minaiyan M, Mirian M, and Lavasanifar A. Development of a RPHPLC method for analysis of docetaxel in tumorbearing mice plasma and tissues following injection of docetaxel-loaded $\mathrm{pH}$ responsive targeting polymeric micelles. Res Pharm Sci. 2020; 15(1):1-13. DOI: 10.4103/1735-5362.278710.

43. Zufía López L, Aldaz Pastor A, Aramendia Beitia JM, Arrobas Velilla J, Giraldez Deiró J. Determination of docetaxel and Paclitaxel in human plasma by highperformance liquid chromatography: validation and application to clinical pharmacokinetic studies. Ther Drug Monit, 2006; 28(2):199-205. DOI: 10.1097/01.ftd.0000189903.46802.1f

44. Jalalizadeh H, Amini M, Ziaee V, Safa A, Farsam H, Shafiee A. Determination of celecoxib in human plasma by high performance liquid chromatography. $\mathrm{J}$ Pharm Biomed Anal, 2004; 35(3): 665-670. DOI: 10.1016/j.jpba.2004.02.005.

45. Guirguis MS, Sattari S, Jamali F. Pharmacokinetics of celecoxib in the presence and absence of interferoninduced acute inflammation in the rat: Application of a novel HPLC assay. J Pharm Pharm Sci, 2001; 4(1):1-6.

46. Abdel-Hamid M, Novotny L, Hamza H. Liquid chromatographic-mass spectrometric determination of celecoxib in plasma using single-ion monitoring and its use in clinical pharmacokinetics. J Chromatogr B Biomed Sci Appl, 2001; 753(2): 401-408. DOI: 10.1016/s0378-4347(00)00574-0.

47. Werner U, Werner D, Pahl A, Mundkowski R, Gillich $\mathrm{M}$, Brune $\mathrm{K}$. Investigating the pharmacokinetic of celecoxib using a new liquid chromatography-mass spectrometry method. Biomed Chromatogr, 2002; 16(1):56-60. DOI: 10.1002/bmc.115.
48. Emami J, Fallah R, Ajami A. A Rapid and Sensitive HPLC Method for the Analysis of Celecoxib in Human Plasma: Application to Pharmacokinetic Studies. Daru. 2008; 16:211-7.

49. Zarghi A, Shafaati A, Foroutan SM, Khoddam A. Simple and rapid high-performance liquid chromatographic method for determination of celecoxib in plasma using UV detection: Application in pharmacokinetic studies. J Chromatogr B Analyt Technol Biomed Life Sci, 2006; 835(1-2): 100-4. DOI: 10.1016/j.jchromb.2006.03.021.

50. Zhang M, Moore GA, Gardiner SJ, Begg EJ. Determination of celecoxib in human plasma and breast milk by high- performance liquid chromatographic assay. J Chromatogr B Analyt Technol Biomed Life Sci, 2006; 830(2): 245-8. DOI: 10.1016/j.jchromb.2005.10.048.

51. Hale TW, McDonald R, Boger J. Transfer of celecoxib into human milk. J Hum Lact, 2004; 20(4): 397-403. DOI: $10.1177 / 0890334404269875$.

52. Schonberger F, Heinkele G, Murdter TE, Brenner S, Klotz U, Hofman U. Simple and sensitive method for the determination of celecoxib in human serum by high-performance liquid chromatography with fluorescence detection. J Chromatogr B Analyt Technol Biomed Life Sci, 2002; 768(2): 255-60. DOI: 10.1016/s1570-0232(01)00588-8.

53. Stormer E, Bauer S, Kirchheiner J, Brockmoller J, Roots I. Simultaneous determination of celecoxib, and carboxy celecoxib in human plasma using gradient reversed-phase liquid chromatography withultraviolet absorbance detection. J Chromatogr B Analyt Technol Biomed Life Sci, 2003; 783(1): 207-12. DOI: 10.1016/s1570-0232(02)00658-x.

54. Chow H, Anavy N, Salazar D, Frank DH, Alberts DS. Determination of celecoxib in human plasma using solid-phase extraction and high- performance liquid chromatography. J Pharm Biomed Anal, 2004; 34(1):167-74. DOI: 10.1016/j.japna.2003.08.018.

55. Guermouche MH, Gharbi A. Simplified solid phase extraction procedure and liquid chromatographic determination of celecoxib in rat serum. Chromatographia, 2004; 60(5-6): 341-5. DOI: 10.1365/s10337-004-0378-6

56. Rose MJ, Woolf EJ, Matuszewski BK. Determination of celecoxib in human plasma by normal phase high performance liquid chromatography with column switching and ultraviolet absorbance detection. J Chromatogr B Biomed Sci Appl, 2000; 738(2):377-85. DOI: 10.1016/s0378-4347(99)00552-6.

57. Brautigam L, Vetter G, Tegeder I, Heinkele G, Geisslinger G. Determination of celecoxib in human plasma and rat microdialysis samples by liquid chromatography tendem mass spectrometry. J Chromatogr B Biomed Sci Appl, 2001; 761(2):203-12. DOI: 10.1016/s0378-4347(01)00333-4.

58. Paulson SK, Kaprak TA, Gresk CJ, Fast DM, Barrata MT, Burton EG, Breau AP, Karim A. Plasma protein 
binding of celecoxib in mice, rat, rabbit, dog and human. Biopharm Drug Dispos, 1999; 20(6): 293-9. DOI: 10.1002/(sici)1099-081x(199909)20:6<293::aidbdd188>3.0.co; $2-x$.

59. Mozumder ZI, Nath LK. A high-performance liquid chromatographic method for estimation of docetaxel in solid lipid nanoparticles. Int J Innov Pharm Sci Res, 2015; 3(8):1058-65.

60. Kim DW, Yousaf AM, Li DX, Kim JO, Yong CS, Cho $\mathrm{KH}$, et al. Development of RP-HPLC method for simultaneous determination of docetaxel and curcumin in rat plasma: validation and stability. Asian J Pharm Sci, 2017; 12(1):105-113. DOI: 10.1016/j.ajps.2016.08.002.

61. Zhang M, Moore GA, Gardiner SJ, Begg EJ. Determination of celecoxib in human plasma and breast milk by high- performance liquid chromatographic assay. J Chromatogr B Analyt Technol Biomed Life Sci, 2006; 830(2): 245-8. DOI: 10.1016/j.jchromb.2005.10.048.

62. Zhao L, Wei YM, Zhong XD, Liang Y, Zhang XM, Li $\mathrm{W}$, et al. PK and tissue distribution of docetaxel in rabbits after i.v. administration of liposomal and injectable formulations. J Pharm Biomed Anal, 2009; 49(4):989-96. DOI: 10.1016/j.jpba.2009.01.016.

63. Hou W, Watters JW, Mcleod HL. Simple and rapid docetaxel assay in plasma by protein precipitation and high-performance liquid chromatography-tandem mass spectrometry. J Chromatogr B Analyt Technol Biomed Life Sci, 2004; 804(2):263-7. DOI: 10.1016/j.jchromb.2004.01.021.

64. Lee SW, Yun MH, Jeong SW, In CH, Kim JY, Seo MH, et al. Development of docetaxel-loaded intravenous formulation, Nanoxel-PM using polymer-based delivery system. J Control Release, 2011; 155(2):26271. DOI: 10.1016/j.jconrel.2011.06.012.
65. Le GD, Gori S, Luo L, Lessard D, Smith DC, Yessine MA, et al. Poly(N-vinylpyrrolidone)-block-poly (D, Llactide) as a new polymeric solubilizer for hydrophobic anticancer drugs: in vitro and in vivo evaluation. J Control Release. 2004; 99(1):83-101. DOI: 10.1016/j.jconrel.2004.06.018.

66. Cho HJ, Park JW, Yoon IS, Kim DD. Surface-modified solid lipid nanoparticles for oral delivery of docetaxel: enhanced intestinal absorption and lymphatic uptake. Int J Nanomedicine, 2014; 9:495-504. DOI: 10.2147/IJN.S56648.

67. Stormer E, Bauer S, Kirchheiner J, Brockmoller J, Roots I. Simultaneous determination of celecoxib, and carboxy celecoxib in human plasma using gradient reversed-phase liquid chromatography with ultraviolet absorbance detection. J Chromatogr B Analyt Technol Biomed Life Sci, 2003; 783(1): 207-12. DOI: 10.1016/S1570-0232(02)00658-X.

68. Emami J, Ghassami N, Ahmadi F. Development and validation of a new HPLC method for determination of lamotrigine and related compounds in tablet formulations. J Pharm Biomed Anal, 2006; 40(4):9991005. DOI: 10.1016/j.jpba.2005.07.045.

69. Vergniol JC, Bruno R, Montay G, Frydman A. Determination of Taxotere in human plasma by a semiautomated high-performance liquid chromatographic method. J. Chromatogr. 1992; 582(1-2):273-8. DOI: 10.1016/0378-4347(92)80333-1.

70. Luo L-h, Zheng P-j, Nie H, Chen Y-c, Tong D, Chen J, et al. Pharmacokinetics and tissue distribution of docetaxel liposome mediated by a novel galactosylated cholesterol derivatives synthesized by lipase-catalyzed esterification in non-aqueous phase. Drug Delivery. 2016;23(4):1282-90.

DOI: 